OPEN ACCESS

Edited by:

Jia Liu

Chongqing University of Arts and Sciences, China

Reviewed by:

Xiaobao Ying,

University of Maryland, College Park,

United States

Weilin Sun

Purdue University, United States

*Correspondence:

Hongbo Qiu

qhb001122@163.com

Anlong Hu

alhu@gzu.edu.cn

Specialty section:

This article was submitted to Microbe and Virus Interactions with

Plants,

a section of the journa

Frontiers in Microbiology

Received: 21 July 2021

Accepted: 30 September 2021

Published: 29 October 2021

Citation:

Zhang Z, Fan J, Feng M, Qiu H and Hu A (2021) Polymerase Chain Reaction-Assisted Evaluation of the

Efficacy of Seed-Treatment Prevention of Sporisorium reilianum

Infection in Sorghum Seedlings.

Front. Microbiol. 12:745144.

doi: 10.3389/fmicb.2021.745144

\section{Polymerase Chain Reaction-Assisted Evaluation of the Efficacy of Seed-Treatment Prevention of Sporisorium reilianum Infection in Sorghum Seedlings}

\author{
Zhi Zhang ${ }^{1}$, Juan Fan ${ }^{2}$, Mucai Feng ${ }^{3}$, Hongbo Qiu ${ }^{1 *}$ and Anlong $\mathrm{Hu}^{2 *}$ \\ ${ }^{1}$ College of Agriculture, Maize Institute, Guizhou University, Guiyang, China, ${ }^{2}$ College of Agriculture, Crop Protection \\ Institute, Guizhou University, Guiyang, China, ${ }^{3}$ Agricultural Technology Extension Center, Weifang, China
}

Head smut, caused by Sporisorium reilianum [(Kuhn) Langdon and Fullerton], is a major disease of sorghum. Seed treatment is considered to be the most effective way to control the disease; however, the pathogen can infect at the seedling stage and the infected plant will not display symptoms until the reproductive stage is reached. The evaluation of the efficacy of seed treatments is time consuming and is dependent upon visible symptoms. Polymerase chain reaction (PCR) methods have the ability to identify pathogens and diagnose their presence at an early stage of infection. In this study, the S. reilianum-specific primer SR3 was used for PCR detection pathogen. We optimized temperature, humidity, and spore quantity test conditions and were able to achieve $>88 \%$ infection incidence in sorghum seedlings. Sorghum seeds were soaked in various concentrations of tebuconazole and planted for 7 days in soil containing $0.2 \%$ teliospores. The efficacy of tebuconazole against $S$. reilianum was evaluated by PCR and recorded as disease incidence. Results indicated that the reduction in disease incidence after exposure to $0.15,0.30,0.45,0.60$, and $0.75 \mu \mathrm{g} / \mathrm{mL}$ tebuconazole was 6.24 , $37.48,67.74,81.24$, and $93.74 \%$, respectively. Significant differences between the concentrations of tebuconazole were observed. The PCR assay represents a valuable tool for evaluating the efficacy of fungicide seed treatments for the control of $S$. reilianum in sorghum under laboratory conditions.

Keywords: sorghum, head smut, seed treatment, PCR, fungicide

\section{INTRODUCTION}

Sorghum [Sorghum bicolor (L.) Moench] is the fifth most important cereal crop produced globally (Mengistu et al., 2019). It is a source of animal feed and fodder, used in traditional and processed foods and beverages, and in the production of biofuel. Head smut of sorghum, caused by Sporisorium reilianum (Kuhn) Langdon and Fullerton [syn. Sphacelotheca reiliana (Kühn) G.P. Clinton and Sorosporium reilianum (Kühn) McAlpine], is an economically important disease of sorghum worldwide (Zhang et al., 2011). The pathogen can infect both maize and sorghum. Although the fungus is a biotroph, infection of a plant results in a complete loss of any harvestable 
seed (Poloni and Schirawski, 2016). Teliospores overwinter in the soil and crop debris and provide primary inoculum for the next cycle of infection. Teliospores are released can remain viable for at least 3 years. Teliospores can also adhere to seed surfaces and during seed storage remain viable for much longer periods. The presence of the pathogen is very difficult to eradicate from the soil once it has become established in a cultivated field (Little et al., 2011).

Current disease management strategies include the use of host resistance and integrated pest management (IPM). Integrated pest management strategies that emphasize reduced pathogen pressure, providing optimal plant growth conditions, and the utilization of disease resistance (or tolerance) represent the future trend in disease control (Anitha et al., 2020). The use of crop protection products is the most common approach used to control $S$. reilianum as most commercially available hybrids lack a high level of resistance. In this regard, seed treatments can be used to reduce the subsequent infection of young seedlings and represent an important component of IPM systems. A variety of seed treatments have been developed to reduce pathogen and insect damage, promote uniform stand development, and increase seedling vigor. Fludioxonil, tebuconazole, sedaxane, triadimenol, and azoxystrobin are chemical fungicides that are commonly used as seed treatments (Lamichhane, 2020).

Sporisorium reilianum infects sorghum at the seedling stage, when they are only $1.5-2 \mathrm{~cm}$ long (Matheussen et al., 1991). After infection, the pathogen continues to proliferate in sorghum tissues without inducing any symptoms in vegetative tissues. The disease manifests itself when the host plant becomes reproductive, and symptoms then become readily visible. In the majority of cases, however, control measures at this stage are not effective. Therefore, developing a convenient, rapid, and accurate detection method for sorghum head smut infection is crucial. Chlorotic flecking along the midrib of maize leaves has been reported as a primary symptom of $S$. reilianum infection (Matyac and Kommedahl, 1985a). Sporisorium reilianum hyphae has also been observed in the epidermal tissues of maize coleoptiles stained with cotton blue (Shen et al., 2006). These assessment approaches, however, have not proven to be consistent.

Polymerase chain reaction (PCR)-based methods can be very effective in confirming the presence of a pathogen and detect infections before symptoms appear (Martinelli et al., 2015). In this regard, PCR-based assays for the detection development of head smut of maize caused by $S$. reilianum are readily available, sensitive, and reliable (Xu et al., 1999; Shen et al., 2006; Ren et al., 2008; Fessehaie and Munkvold, 2010).

As noted, the use of seed treatments with fungicides are a primary method for controlling $S$. reilianum. Since the disease does not show symptoms until the reproductive stage of plant growth, however, conventional methods of evaluating the efficacy of seed treatments using field trials is time-consuming and laborintensive. Therefore, to improve the ability to evaluate the efficacy of fungicidal seed treatments, Anderson et al. developed a realtime PCR-based seedling assay for S. reilianum in maize. In that study, they compared five commercially available formulations of fungicides used as seed treatments for their ability to reduce seedling disease incidence using a PCR analysis of root and mesocotyl tissues (Anderson et al., 2015).

The studies of Anderson et al. (2015) focused on the detection of $S$. reilianum in maize at the seedling stage using PCR technology to determine the efficacy of seed treatments. The extension of their approach to the detection of S. reilianum in sorghum, however, has not been investigated as of now. In fact, due to the slow growth of mycelia on culture media and the low germination rate of teliospores (Shetty and Safeeulla, 1979; Qian, 1990), few lab studies have been conducted on the efficacy of fungicides against S. reilianum. Currently, tebuconazole, applied as a seed treatment, is a major strategy used to protect sorghum seedlings from S. reilianum (Yang et al., 2014). In the present study, a PCR assay was used to detect the presence of $S$. reilianum in sorghum seedlings and determine the efficacy of a sorghum seed treatment with tebuconazole in preventing the establishment of S. reilianum in sorghum seedlings.

\section{MATERIALS AND METHODS}

\section{Sorghum Seeds and Sporisorium reilianum Culture}

Seeds of the glutinous sorghum variety Qiangao 8 were obtained from the Guizhou Subcenter of Chinese Wheat Improvement. The seeds were washed with tap water to remove any fungicidal residues from the surface of the seeds and then dried at room temperature. The dried seeds were then surface sterilized with $1 \%$ sodium hypochlorite in $10 \%$ ethanol for $10 \mathrm{~min}$, rinsed with sterile distilled water three times, and immersed in sterile distilled water for $4 \mathrm{~h}$. This was followed by a hot water treatment in sterile distilled water at $60^{\circ} \mathrm{C}$ for $5 \mathrm{~min}$ to kill any endophytic fungi inside the seeds. Lastly, the seeds were rinsed with sterile distilled water, air-dried, and stored at $4^{\circ} \mathrm{C}$ until use (Huang and Backhouse, 2005).

Teliospores of S. reilianum were collected in August 2020 from naturally infected, smutted panicles of sorghum plants growing in Qianxi county, Bijie City, Guizhou Province, China (Figure 1). Smut galls were broken up and sieved through a 40-mesh sieve to remove plant material and other debris. Teliospores were collected and then air-dried in paper sacks.

Subsequently, $10 \mathrm{mg}$ of teliospores were placed in a $1.5 \mathrm{~mL}$ centrifuge tube and mixed well with $1 \mathrm{~mL}$ sterile water, followed by centrifugation at $4000 \mathrm{rpm}$ for $2 \mathrm{~min}$ at $4^{\circ} \mathrm{C}$ (ST16R, Thermo Fisher SCIENTIFIC, Braunschweig, Germany) and the supernatant was removed along with any floating debris. The precipitated teliospores were treated with $2 \%$ chloramine $\mathrm{T}$ for $15 \mathrm{~min}$, followed by centrifugation as described, after which the supernatant was again removed. The teliospores were then washed three times with distilled water with centrifugation between each wash. A small portion of the teliospores was then plated on YEPS medium (2\% peptone, 2\% sucrose, $1 \%$ yeast extract, and $2 \%$ agar powder) amended with $30 \mathrm{mg}$ penicillin and $200 \mathrm{mg}$ streptomycin per liter, and the plates were cultured at $28^{\circ} \mathrm{C}$ under a $12 \mathrm{~h}$ light/dark cycle (Martinez et al., 2001). The viability of teliospores was evaluated after $3 \mathrm{~d}$ of incubation by monitoring the number of germinated spores out of at least 


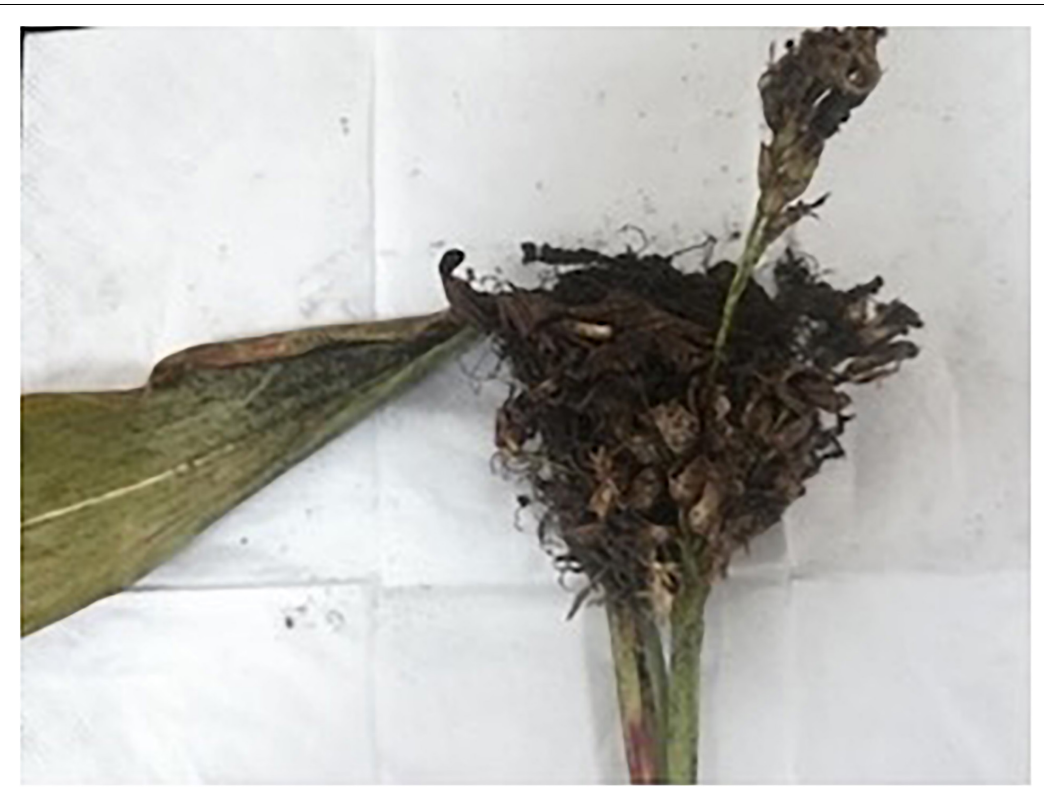

FIGURE 1 | Characteristic symptoms of sorghum head smut caused by S. reilianum in naturally infected, smutted panicles of sorghum plants growing in Qianxi county, Guizhou Province, China.

100 spores in each of four plates. Germination was visually determined using a compound microscope and teliospores were counted as germinated when the length of the germ-tube was longer than one half of the spore diameter. The viability test was repeated three times and the percentage of teliospore germination was calculated based on the collective observations.

\section{Evaluation of Polymerase Chain Reaction Primers for Sporisorium reilianum Amplification}

Two sets of primers were compared to select a set of appropriate PCR primers which provided the best PCR amplification results using S. reilianum genomic DNA as a substrate. The sequences of the primer pair, YGSP1/GSP2, designed by Ren et al. (2008), are YGSP1 (5'-TCGCCG ACGGATGATAATCG-3') and GSP2 (5'-GAGTCACCCGCCCAAAGTTA-3). The sequences of the SR3 primer pair, designed by Xu et al. (1999), are SR3-F (5'-GCAGCCTCAGCATTACT C3') and SR3-R (5'ATACACCTGTGACGGCTG-3). Genomic DNA was extracted from $S$. reilianum mycelia, cultured as previously described, using an Ezup column fungal genomic DNA extraction kit (Sangon Biotech Co., Ltd., Shanghai, China), and used as a template for PCR amplification with the designated primers. The primers were synthesized by Biotech Co. Ltd. (Shanghai, China). The reaction system and procedure are listed in Table 1. PCR amplification was conducted in a Bio-Rad C1000 Touch ${ }^{\mathrm{TM}}$ Thermal Cycler (Bio-Rad, Hemel Hempstead, United Kingdom). The amplified products were assessed on a $1 \%$ agarose gel using a PowerPac electrophoresis (Bio-rad Laboratories, Inc., United States) unit.

The minimal concentration of fungal DNA needed for amplification using the designed primer pairs was also assessed. The concentration of DNA in the extracted DNA solution was quantified using an ultra-low volume spectrophotometer. In brief, $1 \mu \mathrm{L}$ of the extracted DNA solution was diluted with $9 \mu \mathrm{L}$ sterile water, followed by six serial dilutions of 1 in 10 . The diluted DNA solutions were then used as a template for PCR amplification with the designated primer pairs. The amplified products were visualized by $1 \%$ gel electrophoresis.

\section{Seed Treatments}

Five concentrations $(0.15,0.30,0.45,0.60$, and $0.75 \mu \mathrm{g} / \mathrm{mL})$ of tebuconazole were prepared based on a preliminary assay. The level of inhibition determined in the preliminary test at the lowest concentration of tebuconazole was about $10 \%$, while the inhibition level at the highest concentration was about $90 \%$. A stock solution was prepared by dissolving the fungicide in acetone, along with Tween 80 as an emulsifier, and then adding water. A total of 50 seeds were soaked in $10 \mathrm{~mL}$ of the prepared fungicide solutions for $12 \mathrm{~h}$ and then removed and air dried in preparation for subsequent use. Three replicate lots of seed were treated at each fungicide concentration and a solution containing acetone and Tween80, but no fungicide, was used as a control.

TABLE 1 | Reaction systems and PCR protocols using YGSP and SR3 primer pairs for the detection of $S$. reilianum in sorghum seedlings.

\begin{tabular}{|c|c|c|c|}
\hline \multirow{3}{*}{$\begin{array}{l}\text { Reaction system } \\
\text { Primer F } 0.5 \mu \mathrm{L} \text {, Primer R } 0.5 \mu \mathrm{L}, 2 \text { xTaq } \\
\text { PCR Master Mix } 10 \mu \mathrm{L} \text {, ddH2O } 8 \mu \mathrm{L}\end{array}$} & \multicolumn{2}{|c|}{ Reaction program } & \multirow[b]{2}{*}{$3 \mathrm{~min}$} \\
\hline & \multicolumn{2}{|l|}{$94^{\circ} \mathrm{C}$} & \\
\hline & $94^{\circ} \mathrm{C}$ & \multirow[t]{2}{*}{$\uparrow$} & $30 \mathrm{~s}$ \\
\hline & $50^{\circ} \mathrm{C}$ & & $30 \mathrm{~s}$ \\
\hline & $72^{\circ} \mathrm{C}$ & $35 \mathrm{cycl}$ & $50 \mathrm{~s}$ \\
\hline & $72^{\circ} \mathrm{C}$ & & $5 \mathrm{~min}$ \\
\hline
\end{tabular}




\section{Laboratory Assays of Disease Incidence}

The soil used for planting the sorghum was a light sandy clay collected from the teaching farm of Guizhou University and had a pH of $5.7\left(\mathrm{H}_{2} \mathrm{O}\right)$. The soil was autoclaved for sterilization and then sifted for use.

The main factors affecting $S$. reilianum infection are soil moisture and temperature (Baier and Kruger, 1962; Matyac and Kommedahl, 1985b). Therefore, the incubation conditions were optimized by adjusting the soil moisture, temperature, and spore quantity present in the soil. The optimized protocol for obtaining the highest level of disease incidence was as follows: Soil was mixed with $0.2 \%$ (by weight) teliospores and then added to a plug-designed planting tray. Sterilized sorghum seeds were then planted at 2 seeds per well. The seeds were placed $2 \mathrm{~cm}$ deep in the pathogen-contaminated soil. The plug trays were then placed in an incubator and cultured at $10^{\circ} \mathrm{C}, 60 \%$ humidity, and $20 \%$ soil moisture. The trays were then transferred to a greenhouse set at $25^{\circ} \mathrm{C}$ and a $12 \mathrm{~h}$ light/dark cycle. Seedlings were collected after seven days when they were $2-3 \mathrm{~cm}$ in length. A total of 18 similarsized seedlings were collected from each replicate tray and used for the extraction of genomic DNA.

\section{Extraction of Genomic DNA From the Sorghum Seedlings}

Eighteen seedlings were used within each replicate for DNA extraction. Genomic DNA was extracted from individual seedlings using a DNA extraction kit (Sangon Biotech Co., Ltd., Shanghai, China). Seedling were cleaned of visible soil by rinsing under running tap water and then surface disinfected by submersion in $10 \% \mathrm{NaOCl}$ solution with agitation for $2 \mathrm{~min}$. Plants were rinsed twice in sterile water for $30 \mathrm{~s}$ each time (Anderson et al., 2015). Seedling were placed in a sterilized mortar, ground into a powder with a pestle in liquid nitrogen, and then immediately transferred into a $1.5 \mathrm{~mL}$ Eppendorf tube. Next, $800 \mu \mathrm{L}$ of CTAB extraction buffer solution (preheated in a water bath to $65^{\circ} \mathrm{C}$ ) was added to each of the tubes containing the ground seedling tissues and the mixture was then thoroughly mixed several times on a vortexer ( $5 \mathrm{~min} / \mathrm{time}$ ) for a total of $20 \mathrm{~min}$. The seedlings were subsequently centrifuged for $2 \mathrm{~min}$ $\left(12000 \mathrm{rpm}, 4^{\circ} \mathrm{C}\right)$. The supernatant was then removed and mixed with an equal volume of phenol: chloroform (1:1, $400 \mu \mathrm{L}$ each) and the mixture was then centrifuged for $10 \mathrm{~min}$. The resulting supernatant was then mixed with an equal volume of chloroform, followed by centrifugation for $2 \mathrm{~min}$. This process was repeated several times until no protein layer was visible. Genomic DNA was precipitated from supernatant by addition of 2 volumes of ice-cold absolute ethanol and storage at $-20^{\circ} \mathrm{C}$ for $1 \mathrm{~h}$, followed by centrifugation for $2 \mathrm{~min}$. The resulting supernatant was discarded, and the precipitated samples of genomic DNA were washed with $70 \%$ ethanol, precipitated twice, dried at room temperature, and finally dissolved in $50 \mu \mathrm{L}$ of DEPC treated water for subsequent use.

\section{PCR Detection}

The genomic DNA obtained from sorghum seedlings was used as a template for PCR amplification using the SR3 primers. The reaction system and procedure are provided in Table 1. The PCR products were detected using $1 \%$ agarose gel electrophoresis. The incidence of infection of seedlings by the smut pathogen S. reilianum was determined by the analysis of bands present on the agarose gels.

\section{Evaluation of Fungicide Efficacy by Inhibition of Teliospore Germination}

Inhibition of spore germination is a common method to determine the efficacy of fungicides. Therefore, the $\mathrm{EC}_{50}$ and $\mathrm{EC}_{95}$ of tebuconazole were determined by measuring teliospore germination after exposure to the prepared solutions of tebuconazole.

The teliospores were fumigated for $45 \mathrm{~min}$ with a mixture of $10 \mathrm{~mL} / \mathrm{m}^{3} \quad 40 \%$ formaldehyde and $5 \mathrm{~g} / \mathrm{m}^{3}$ potassium permanganate (Liu et al., 2007). Spore suspensions were prepared with sterile water and adjusted to about 100 spores per field of microscope. A tebuconazole acetone solution was added to sterilized and slightly cooled YEPS medium $(\mathrm{pH}=7.0)$ and fully mixed. Medium amended with an equal amount of acetone was used as a control. Three replicates were used for each concentration of fungicide. Five concentrations of fungicide $(0.02,0.04,0.08,0.16$, and $0.32 \mu \mathrm{g} / \mathrm{mL})$ were used based on a preliminary assay. The level of inhibition determined in the preliminary test at the lowest concentration of tebuconazole was about $10 \%$, while the inhibition level at the highest concentration was about $90 \%$. A $0.1 \mathrm{~mL}$ drop of spore suspension was evenly distributed on the surface of each YEPS plate $(9 \mathrm{~cm})$, and the plates were then placed in an incubator at $28^{\circ} \mathrm{C}$ (Jiang et al., 2004). The rate of spore germination was determined after $48 \mathrm{~h}$ of culture by counting 100 spores in three different fields of view (300 spores per plate). A spore was considered germinated when the length of the germ-tube was longer than one half of the spore diameter.

\section{Data Analysis}

The level of infection and teliospore germination were calculated using the following equation:

$$
\text { Inhibition rate }=\frac{C K-T}{C K} \times 100 \%
$$

$\mathrm{T}$ and $\mathrm{CK}$ infection in the seedling assay were determined by a positive PCR amplification in the treated and control seedlings. T and CK in the teliospore germination assay were determined by observations of spore germination in the treated and control teliospores.

The $\mathrm{EC}_{50}$ and $\mathrm{EC}_{95}$ values were calculated by regressing the percentage inhibition (probability value transformed) against the logarithm value of the fungicide concentration (log transformed). Regression analysis was performed using Microsoft Excel 2007 software (Li et al., 2015).

\section{Analysis of Variance}

Analysis of Variance between treatments was analyzed using the DPS $^{\circledR}$ (Data Processing System, version7.05; Hangzhou RuiFeng Information Technology Co. Ltd., Hangzhou, China) software. 


\section{RESULTS}

\section{Sporisorium reilianum Colony Morphology}

Many small colonies of $S$. reilianum were present on the YEPS medium after incubation for 10 days (Figure 2A). A single colony was selected and cultured on YEPS medium to make observations of colony morphology (Figure 2B). All the morphological observations of colony appearance were consistent with the description of S. reilianum in the Manual of Fungal Identification (Wei, 1979). The percentage of teliospore germination was $67.5 \%$.

\section{PCR-Amplification of Sporisorium reilianum Genomic DNA With Select Primers}

The expected band size by SR3 primer was $680 \mathrm{bp}$. The PCR products amplified by SR3 yielded four clear, distinct bands on an agarose gel (Figure 3). In contrast, only one product was generated by the PCR-amplification using YGSP primers, evidenced as a single band with low definition on an agarose gel. As a result, the SR3 primers were selected for assessment of the presence of $S$. reilianum, based on the clarity of the bands that were produced by PCR-amplification of S. reilianum genomic DNA.

\section{Limit of Detection of Sporisorium reilianum Genomic DNA by PCR}

The concentration of the extracted, genomic DNA of S. reilianum was $107 \mathrm{ng} / \mu \mathrm{L}$, which was diluted in 10-fold dilution series to obtain concentrations of $10.7 \mathrm{ng} / \mu \mathrm{L}, 1.07 \mathrm{ng} / \mu \mathrm{L}$, $1.07 \times 10^{-1} \mathrm{ng} / \mu \mathrm{L}, 1.07 \times 10^{-2} \mathrm{ng} / \mu \mathrm{L}, 1.07 \times 10^{-3} \mathrm{ng} / \mu \mathrm{L}$, and $1.07 \times 10^{-4} \mathrm{ng} / \mu \mathrm{L}$. The various concentrations $S$. reilianum genomic DNA were then used as a template for PCR-amplification with the SR3 primers. As shown in Figure 4, the designated target band was amplified and visible on an agarose gel at concentrations of $10.7 \mathrm{ng} / \mu \mathrm{L}, 1.07 \mathrm{ng} / \mu \mathrm{L}$, and $1.07 \times 10^{-1} \mathrm{ng} / \mu \mathrm{L}$ of $S$. reilianum genomic DNA. The band size was approximately $680 \mathrm{bp}$. The amplification using the $10.7 \mathrm{ng} / \mu \mathrm{L}$ concentration of genomic DNA produced the strongest (brightest) band, while concentrations of $1.07 \times 10^{-2} \mathrm{ng} / \mu \mathrm{L}, 1.07 \times 10^{-3} \mathrm{ng} / \mu \mathrm{L}$, and $1.07 \times 10^{-4} \mathrm{ng} / \mu \mathrm{L}$ did not produce any visible PCR products. Therefore, a

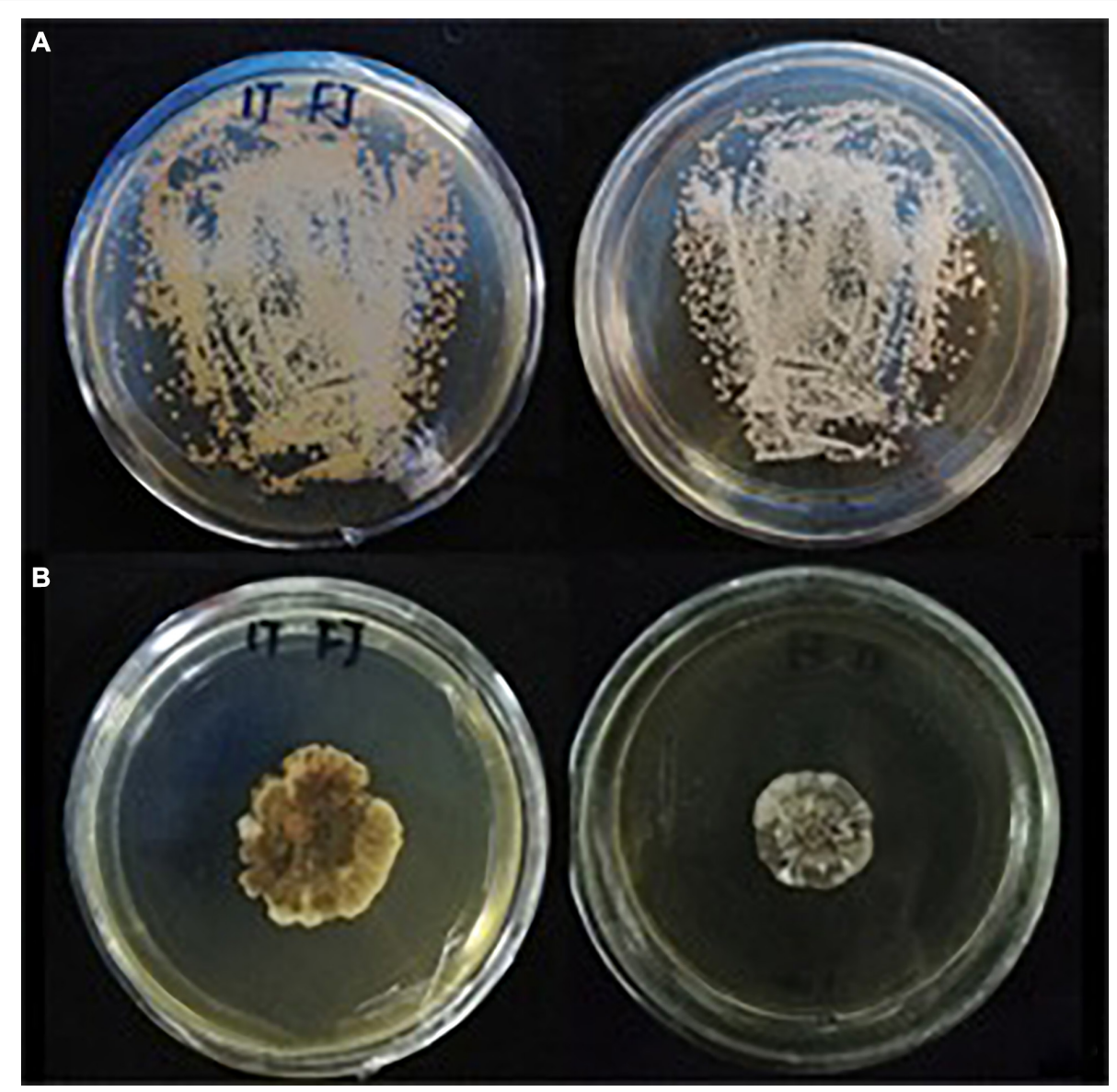

FIGURE 2 | Morphology of S. reilianum colonies growing on YEPS medium at $28^{\circ} \mathrm{C}$ with a $12 \mathrm{~h}$ light/dark cycle. (A) a small amount of teliospore suspension was distributed on YEPS medium and cultured for $10 \mathrm{~d}$; (B) single colony cultured on YEPS medium for $30 \mathrm{~d}$. 


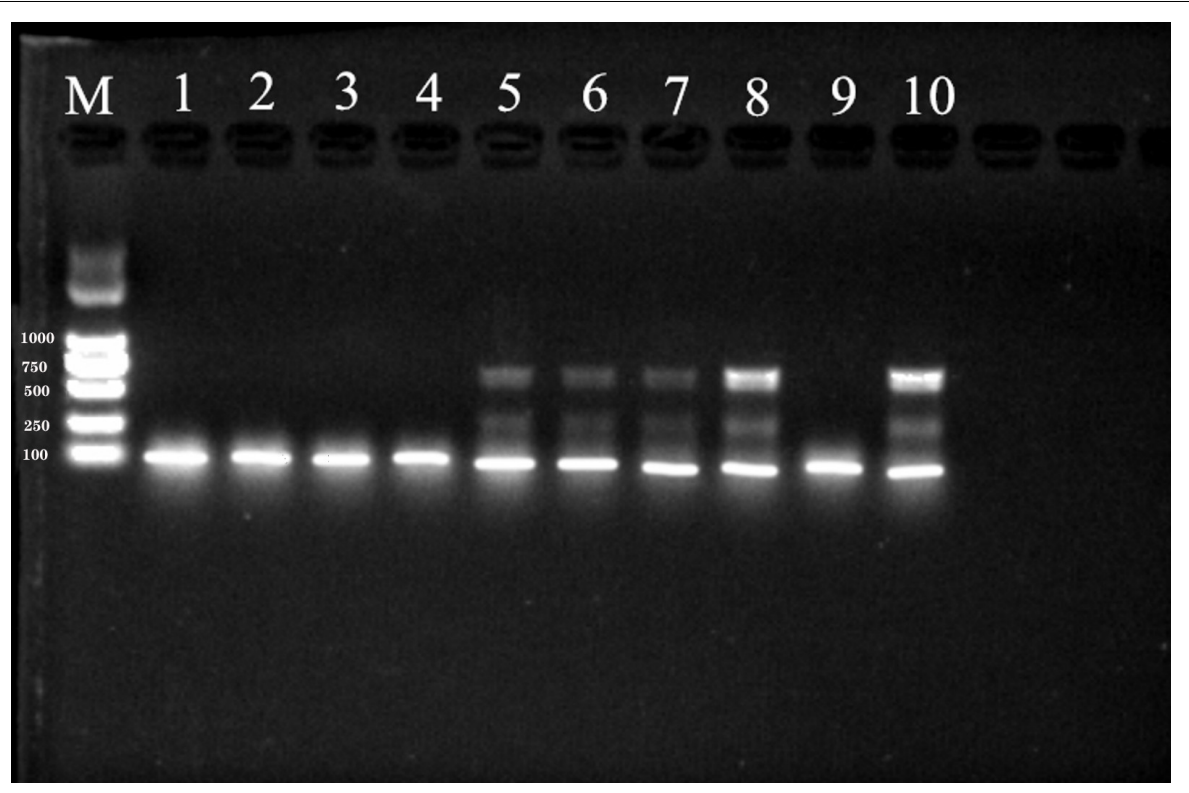

FIGURE 3 | PCR products amplified from genomic DNA of S. reilianum using YGSP (lane 1-5) and SR3 (lane 6-10) primer pairs, subsequently separated on a 1\% agarose gel. Lane M is DNA ladder DL2000.

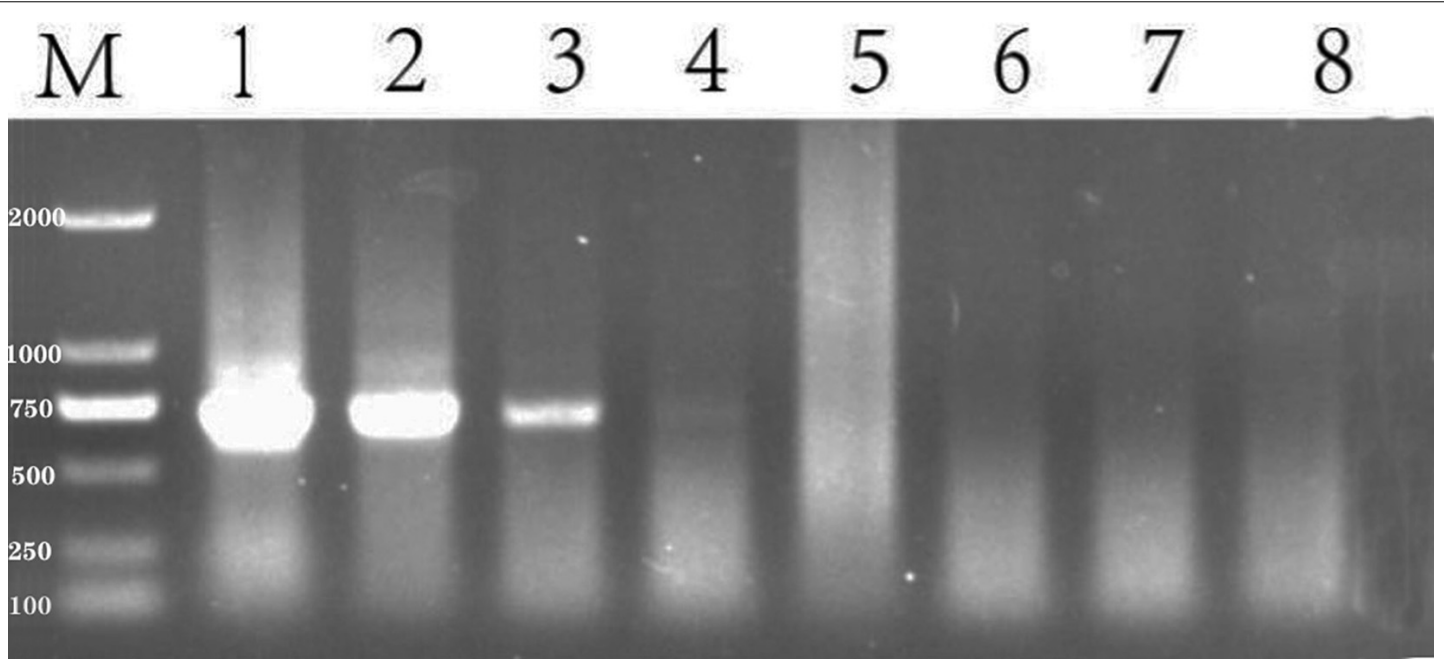

FIGURE 4 | Sensitivity of detection of $S$. reilianum using the SR3 primer pair. PCR products amplified from a 10-fold dilution series of S. reilianum genomic DNA and visualized on a $1 \%$ agarose gel. Lane $1: 107 \mathrm{ng} / \mu \mathrm{L}$, Lane 2: $10.7 \mathrm{ng} / \mu \mathrm{L}$, Lane 3: $1.07 \mathrm{ng} / \mu \mathrm{L}$, Lane $4: 1.07 \times 10^{-1} \mathrm{ng} / \mu \mathrm{L}, \mathrm{Lane} 5: 1.07 \times 10^{-2} \mathrm{ng} / \mu \mathrm{L}, \mathrm{Lane}$ $6: 1.07 \times 10^{-3} \mathrm{ng} / \mu \mathrm{L}$, Lane $7: 1.07 \times 10^{-4} \mathrm{ng} / \mu \mathrm{L}$. Lane M: DNA ladder DL2000.

concentration of $1.07 \mathrm{ng} / \mu \mathrm{L}$ genomic DNA was considered to be the limit for the detection of $S$. reilianum.

\section{Efficacy of Seed Treatments Against Sporisorium reilianum Infection Determined by PCR}

The incidence of pathogen infection of sorghum seedlings was assessed after seven days of seedling growth. Incidence was determined to be positive if S. reilianum was detected by PCR, while negative PCR results were considered to be a non-infected seedling (Figure 5). Treatment efficacy was determined by the number of negative vs. positive PCR results. The fewer positive PCRs observed, the better the efficacy of the fungicidal treatment.

The incidence of infection in seeds treated with $0.15,0.30$, $0.45,0.60$, and $0.75 \mu \mathrm{g} / \mathrm{mL}$ tebuconazole was $83.33 \%, 55.56 \%$, $27.78 \%, 16.67 \%$, respectively, while the incidence of infection in the untreated control was $88.88 \%$ (Figure 6). Conversely, the infection inhibition rate was $6.24 \%, 37.48 \%, 67.74 \%, 81.24$, and 93.74\%, respectively.

A linear regression of the level of inhibition vs. the logarithmic concentration of tebuconazole, yielded the equation 


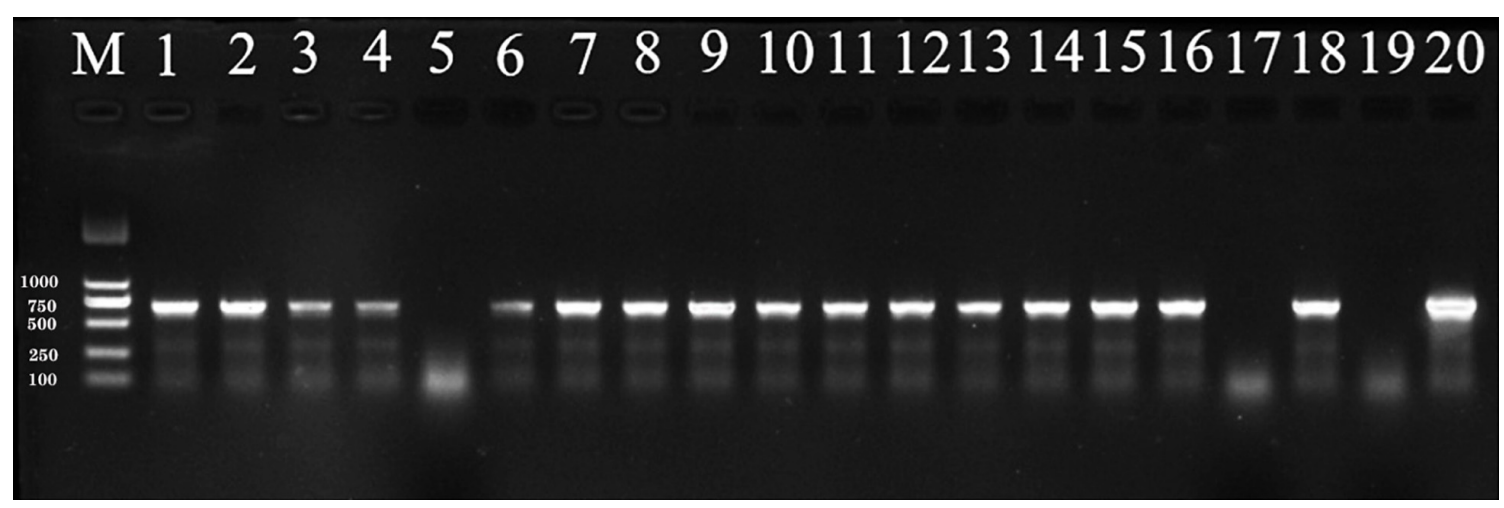

FIGURE 5 | PCR products amplified from DNA extracted from sorghum seedings and visualized by $1 \%$ agarose gel electrophoresis. Sorghum seeds were planted in soil containing $0.2 \%$ (by weight) teliospores of S. reilianum. After 3 days of incubation at $10^{\circ} \mathrm{C}, 20 \%$ soil moisture, and $60 \%$ relative humidity, the planted seed trays were transferred to a greenhouse $\left(25^{\circ} \mathrm{C}\right.$ and a 12-h light/dark cycle) for 4 days after which the seedlings were collected for DNA extraction. Lane M: DNA ladder DL2000. Lane 1-18: sorghum seedings. 19: negative control (Seedlings from pathogen-free soil); 20: positive control (DNA from S. reilianum mycelia).

$\mathrm{y}=6.9494+4.2741 \mathrm{x}(r=0.9953)$. Based on this equation, the $\mathrm{EC}_{50}$ value was calculated to be $0.35 \mu \mathrm{g} / \mathrm{mL}$ tebuconazole (95\% confidence limit: $0.33-0.37 \mu \mathrm{g} / \mathrm{mL}$ ), and the $\mathrm{EC}_{95}$ was $0.85 \mu \mathrm{g} / \mathrm{mL}$ (95\% confidence limit: $0.78-0.92 \mu \mathrm{g} / \mathrm{mL}$ ).

\section{Efficacy of Tebuconazole Against Sporisorium reilianum Determined by Inhibition of Spore Germination}

The percentage of teliospore germination after $48 \mathrm{~h}$ of incubation on media amended with $0.02,0.04,0.08,0.16$, and $0.32 \mu \mathrm{g} / \mathrm{mL}$ tebuconazole was $73.58 \%, 52.44 \%, 26.83 \%, 13.00 \%$,

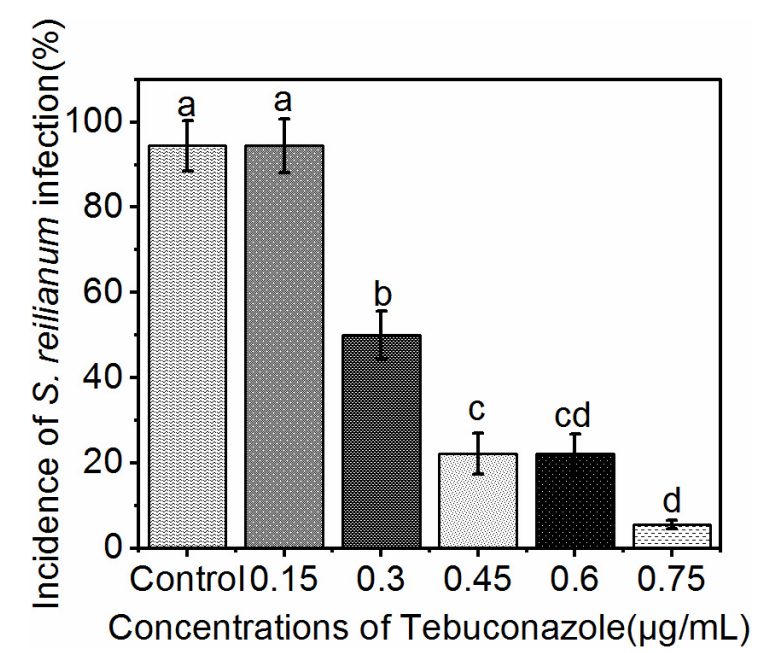

FIGURE 6 | Incidence of S. reilianum infection in sorghum seedlings determined by positive PCR reactions. Sorghum seeds were treated with five different concentrations of tebuconazole ( $\mathrm{x}$-axis), then planted in soil containing $0.2 \%$ (by weight) teliospores of $S$. reilianum and grown 7 days. Each bar represents the mean \pm se $(n=3)$ level of disease incidence (y-axis). Different lowercase letters indicate a significant difference between the different concentration of tebuconazole $(p<0.05)$. and $4.06 \%$, respectively. The germination on media without tebuconazole was $82.00 \%$. Conversely, the teliospore germination inhibition rate was $10.27 \%, 47.56 \%, 67.28 \%, 84.14$, and $95.04 \%$, respectively (Figure 7).

Linear regression of the level of inhibition vs. the logarithmic concentration of tebuconazole yielded the equation $\mathrm{y}=7.8689+2.2968 \mathrm{x}(r=0.9837)$. Based on this equation, the $\mathrm{EC}_{50}$ value was calculated to be $0.056 \mu \mathrm{g} / \mathrm{mL}$ (95\% confidence limit: $0.046-0.070 \mu \mathrm{g} / \mathrm{mL})$ and the $\mathrm{EC}_{95}$ was $0.293 \mu \mathrm{g} / \mathrm{mL}(95 \%$ confidence limit: $0.210-0.410 \mu \mathrm{g} / \mathrm{mL}$ ).

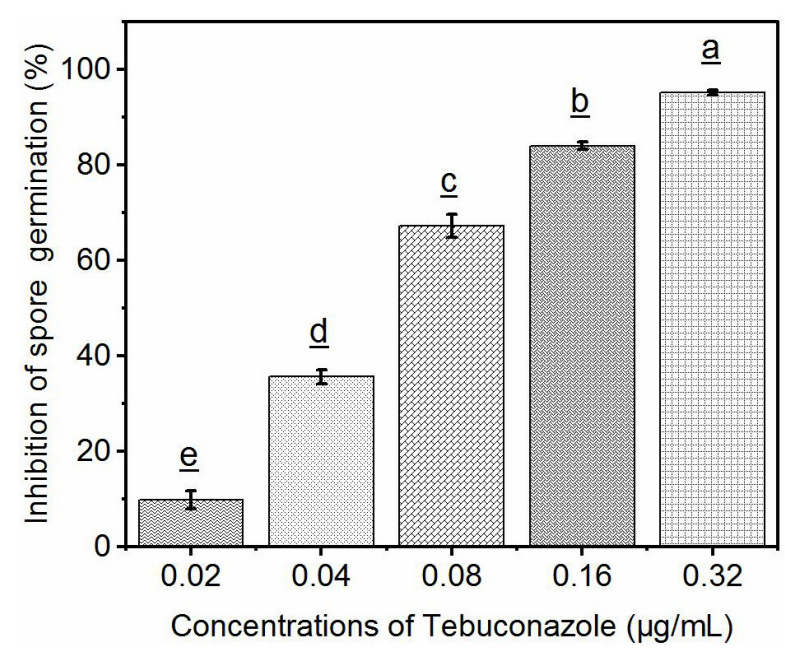

FIGURE 7 | Efficacy of tebuconazole against $S$. reilianum determined by inhibition of spore germination. Spore suspension was evenly distributed on the surface of YEPS plate containing different concentrations of fungicides, after $48 \mathrm{~h}$ of culture at $28^{\circ} \mathrm{C}$, the rate of spore germination was determined by counting 100 spores in three different fields of view (300 spores per plate). A spore was considered germinated when the length of the germ-tube was longer than one half of the spore diameter. Each bar represents the mean \pm se $(n=3)$. Different lowercase letters indicate a significant difference between the different concentration of tebuconazole $(p<0.05)$. 


\section{DISCUSSION}

The efficacy of fungicides can be tested under either laboratory or field conditions. Inhibition of spore germination and mycelial growth are typically the parameters measured under laboratory conditions while a disease index is calculated to determine fungicidal efficacy in the field.

Tebuconazole is one of the most commonly used fungicides in agriculture and efficacy under laboratory conditions has been extensively examined. For example, the $\mathrm{EC}_{50}$ and $\mathrm{EC}_{90}$ values, based on the inhibition of mycelial growth, for Alternaria mali are 0.034 and $0.587 \mu \mathrm{g} / \mathrm{mL}$, and 0.019 and $0.394 \mu \mathrm{g} / \mathrm{mL}$ for Physalospora. piricola, respectively (Jian-lu et al., 2007). The mean $\mathrm{EC}_{50}$ of tebuconazole, based on the inhibition of mycelial growth of 10 Fusarium graminearum isolates, was reported to be $0.19 \mathrm{mg} / \mathrm{L}$ (Avozani et al., 2014). The $\mathrm{EC}_{50}$ and $\mathrm{EC}_{90}$ values for $43 \%$ tebuconazole suspension concentrates against Phomopsis asparagi is 7.4241 and $47.1322 \mathrm{mg} / \mathrm{L}$, respectively (Jia et al., 2009). $\mathrm{EC}_{50}$ and $\mathrm{EC}_{95}$ of tebuconazole for sensitive strains of Sclerotinia homoeocarpa is 0.078 and $1.943 \mu \mathrm{g} / \mathrm{mL}$, respectively (Couch, 2003).

In our study, a PCR method was used to determine infection incidence of $S$. reilianum in sorghum seedlings. Based on our dose-response data, we performed a linear regression and determined an $\mathrm{EC}_{50}(0.35 \mu \mathrm{g} / \mathrm{mL})$ and an $\mathrm{EC}_{95}(0.85 \mu \mathrm{g} / \mathrm{mL})$ value for tebuconazole using the derived regression equation. The $\mathrm{EC}_{50}$ value for tebuconazole determined by PCR was higher than most it was in reports of several other pathogens that determined efficacy based on the inhibition of mycelial growth and/or teliospore germination. Our present results suggest that inhibition of spore germination or mycelial growth alone may not completely reflect efficacy. Spores in the soil that are not in direct contact with the seed may still germinate and their mycelia may infect the germinated seedling, even though mycelial growth may be inhibited. Thus, in actuality a higher concentration is needed to prevent infection than may be indicated in a petri dish assay. $\mathrm{EC}_{50}(0.056 \mu \mathrm{g} / \mathrm{mL})$ and $\mathrm{EC}_{95}(0.293 \mu \mathrm{g} / \mathrm{mL})$ value determined by inhibition of spore germination were all lower than these determined by PCR method. This result was consistent with our conclusion above. Therefore, we assume that our calculations are reliable under the conditions used in our study.

An important objective in our study was to improve the level of infection achieved in untreated, control seedlings. Methods for artificial inoculation using $S$. reilianum have been previously reported (Xiaowei Zhou et al., 2017). Four methods were used to render different maize varieties highly susceptible to infection by $S$. reilianum. The methods included injection of coleoptiles, mixing teliospores in the soil, root irrigation with water containing teliospores, and soaking seeds in water containing teliospores. Their results revealed that injection of corn coleoptiles provided the highest levels of infection. Since the purpose of our study was to evaluate the efficacy of tebuconazole as a seed treatment, the method of mixing the soil with teliospores was utilized, as it also more closely reflects field conditions.
The optimal temperature for infection of sorghum by S. reilianum has been reported to be $21 \sim 28^{\circ} \mathrm{C}$, with a low to medium level of soil moisture (Wu et al., 1981). It has reported that $S$. reilianum infection was the highest when soil moisture content was $15.5 \%$. In the present study, a $0.2 \%$ concentration of teliospores in soil and a $20 \%$ of soil moisture level provided a high rate of infection. Notably, a previous study indicated that a suitable soil temperature for S. reilianum infection was $20 \sim 30^{\circ} \mathrm{C}$, with $35^{\circ} \mathrm{C}$ as the highest temperature and $10^{\circ} \mathrm{C}$ as the lowest temperature (Zhang, 1980; Wang et al., 2002). The approach used in the present study to achieve a high rate of infection was as follows. Seedlings were first placed at the minimum temperature of $10^{\circ} \mathrm{C}$ for 3 days and then transferred to $25^{\circ} \mathrm{C}$. The objective of placing the seedlings at $10^{\circ} \mathrm{C}$ for the first three days was to stress the plants and make them susceptible to pathogen infection. The rate of infection achieved in our study was $88.88 \%$, which is consistent with the results reported by Craig and Frederiksen (1992) and Jiang et al. (2014).

Modern approaches for detecting fungal plant pathogens utilize high-throughput molecular strategies. These include qualitative polymerase chain reaction ( $\mathrm{qPCR})$, real-time, quantitative PCR (RT-qPCR), nested PCR, loop-mediated isothermal amplification (LAMP), rolling circle amplification (RCA), and nucleic acid sequence-based amplification (NASBA) (Hariharan and Prasannath, 2021). Thus, PCR has become an essential diagnostic tool.

Real-time, quantitative PCR (RT-qPCR) has become increasingly used in plant pathogen diagnostics (Mirmajlessi et al., 2015). An advantage of RT-qPCR over qPCR is that the former is quantitative and can provide an estimate of the level of infection (i.e., how much pathogen is present) (McCartney et al., 2003). In our study, however, qPCR was selected as a diagnostic tool since we were simply trying to determine infection incidence, so a quantitative assessment was not required, and because $\mathrm{QPCR}$ is easier to conduct than RT-qPCR, the latter of which also requires greater expertise. In summary, due to the slow growth of mycelia and the low germination rate of teliospores of S. reilianum, as well as the time-consuming nature of field observations and evaluations, PCR-based evaluation of sorghum seedlings provides an excellent approach for evaluating the efficacy of fungicidebased seed treatments in preventing $S$. reilianum infection of sorghum seedlings.

\section{DATA AVAILABILITY STATEMENT}

The original contributions presented in the study are included in the article/supplementary material, further inquiries can be directed to the corresponding authors.

\section{AUTHOR CONTRIBUTIONS}

$\mathrm{HQ}$ and $\mathrm{AH}$ contributed to conception and design of the study. $\mathrm{ZZ}$ performed the experiments, analysis, and wrote first draft of 
the manuscript. JF and MF validated the methodology, analysis, and provided supervision. All authors contributed to manuscript revision and read and approved the submitted version.

\section{FUNDING}

This research was supported by the National Natural Science Foundation of China (32060488 and 31760531) and the

\section{REFERENCES}

Anderson, S., Simmons, H., and Munkvold, G. (2015). Real-time PCR assay for detection of Sphacelotheca reiliana infection in maize (Zea mays) seedlings and evaluation of seed treatment efficacy. Plant Dis. 99, 1847-1852. doi: 10.1094/ PDIS-07-14-0776-RE

Anitha, K., Das, I., Holajjer, P., Sivaraj, N., Reddy, C. R., and Balijepalli, S. B. (2020). "Sorghum diseases: diagnosis and management," in Sorghum in the 21st Century: Food-Fodder-Feed-Fuel for a Rapidly Changing World, eds A. K. Are, B. V. Bhat, C. R. Reddy, H. S. Talwar, T. J. Dalton, and V. A. Tonapi (Singapore: Springer), 565-619. doi: 10.1007/978-981-15-8249-3_23

Avozani, A., Reis, E. M., and Tonin, R. B. (2014). In vitro sensitivity reduction of Fusarium graminearum to DMI and QoI fungicides. Summa Phytopathol. 40, 358-364. doi: 10.1590/0100-5405/1970

Baier, W., and Kruger, W. (1962). Sphacelotheca reiliana on maize. II. Field studies on the effect of soil conditions. South Afr. J. Agric. Sci. 5, 183-190.

Couch, H. B. (2003). Strategies for preventing and managing fungicide resistance. Golf Course Manag. 71, 111-115.

Craig, J., and Frederiksen, R. (1992). Comparison of sorghum seedling reactions to Sporisorium reilianum in relation to sorghum head smut resistance classes. Plant Dis. 76, 314-318. doi: 10.1094/PD-76-0314

Fessehaie, A., and Munkvold, G. (2010). "Real-time PCR to measure head smut infection in maize seedlings," in Phytopathology, ed. N. Wang Vol. 100, (Saint Paul, MN: American Phytopathological Society), S36-S36.

Hariharan, G., and Prasannath, K. (2021). Recent advances in molecular diagnostics of fungal plant pathogens: a mini review. Front. Cell. Infect. Microbiol. 10:829. doi: 10.3389/fcimb.2020.600234

Huang, L. D., and Backhouse, D. (2005). Induction of defense responses in roots and mesocotyls of sorghum seedlings by inoculation with fusarium thapsinum and $f$. proliferatum, wounding and light. J. Phytopathol. 153, 522-529. doi: 10.1111/j.1439-0434.2005.01013.x

Jia, H., Zhao, J., Li, S., and Chen, D. (2009). Toxicity and efficacy of six fungicides against Phomopsis asparagi (Sacc.) Bubak. Agrochemicals $12: 3$

Jiang, X. Y., Yi, M. Q., Wang, K. Y., and Tian, W. X. (2004). Inhibition and toxicity of four fungicides on Sphacelotheca reiliana. Chinese J. Pestic. Sci. 8, 375-376. doi: 10.16820/j.cnki.1006-0413.2009.12.021

Jiang, Y., Xu, X., Hu, L., Xu, J., and Zhang, M. (2014). Effect of head smut pathogen on activities of protective enzymes in sorghum. J. Shenyang Agric. Univ. 45, 617-620.

Jian-lu, Q., Xiao-jun, L., Yong, Z., and Kun, F. (2007). Evaluation of fungitoxicity of tebuconazole against Alternaria mali and Physalospora piricola on apple in laboratory and in field. Chinese J. Pestic. Sci. 9, 149-152.

Lamichhane, J. R. (2020). Parsimonious use of pesticide-treated seeds: an integrated pest management framework. Trends Plant Sci. 25, 1070-1073. doi: 10.1016/j. tplants.2020.08.002

Li, J. L., Liu, X. Y., Xie, J. T., Di, Y. L., and Zhu, F. X. (2015). A comparison of different estimation methods for fungicide EC50 and EC95 values. J. Phytopathol. 163, 239-244. doi: 10.1111/jph.12312

Little, C. R., Perumal, R., Tesso, T. T., Prom, L. K., Odvody, G. N., and Magill, C. W. (2011). Sorghum pathology and biotechnology-A fungal disease perspective: part I. Grain mold, head smut, and ergot. Eur. J. Plant Sci. Biotechnol. $6,10-30$.
Guizhou Province Science and Technology Cooperation Plan [LH (2015)7671].

\section{ACKNOWLEDGMENTS}

Many thanks to Guozhong Luo of Fujian Agriculture and Forestry University and Xiangbo Luo of Hubei University for their technical guidance in this study.

Liu, H. L., Wang, X. F., Liu, H., Shen, G. S., and Xie, L. H. (2007). Study on germination conditions of teliospore of maize head smut. China Plant Protect. 27, 5-8.

Martinelli, F., Scalenghe, R., Davino, S., Panno, S., Scuderi, G., Ruisi, P., et al. (2015). Advanced methods of plant disease detection. A review. Agron. Sustain. Dev. 35, 1-25. doi: 10.1007/s13593-014-0246-1

Martinez, C., Buée, M., Jauneau, A., Bécard, G., Dargent, R., and Roux, C. (2001). Effects of a fraction from maize root exudates on haploid strains of Sporisorium reilianum f. sp. zeae. Plant Soil 236, 145-153. doi: 10.1023/A:10127769 19384

Matheussen, A.-M., Morgan, P. W., and Frederiksen, R. A. (1991). Implication of gibberellins in head smut (Sporisorium reilianum) of Sorghum bicolor. Plant Physiol. 96, 537-544. doi: 10.1104/pp.96.2.537

Matyac, C. A., and Kommedahl, T. (1985a). Factors affecting the development of head smut caused by Sphacelotheca reiliana on corn. Phytopathology 75, 577-581. doi: 10.1094/Phyto-75-577

Matyac, C. A., and Kommedahl, T. (1985b). Occurrence of chlorotic spots on corn seedlings infected with Sphacelotheca reiliana and their use in evaluation of head smut resistance. Plant Dis. 69, 251-254. doi: 10.1094/PD69-251

McCartney, H. A., Foster, S. J., Fraaije, B. A., and Ward, E. (2003). Molecular diagnostics for fungal plant pathogens. Pest Manag. Sci. 59, 129-142. doi: 10. 1002/ps.575

Mengistu, G., Shimelis, H., Laing, M., and Lule, D. (2019). Assessment of sorghum genetic resources of Ethiopia for anthracnose (Colletotrichum sublineolum Henn.) resistance and agronomic traits.”. J. Phytopathol. 167, 667-678. doi: 10.1111/jph. 12861

Mirmajlessi, S. M., Loit, E., Maend, M., and Mansouripour, S. M. (2015). Real-time PCR applied to study on plant pathogens: potential applications in diagnosis-a review. Plant Protect. Sci. 51, 177-190. doi: 10.17221/104/ 2014-PPS

Poloni, A., and Schirawski, J. (2016). Host specificity in Sporisorium reilianum is determined by distinct mechanisms in maize and sorghum. Mol. Plant Pathol. 17, 741-754. doi: 10.1111/mpp. 12326

Qian, J. J. Z. (1990). Studies on the germination of the telispore of maize head smut pathogen. J. Plant Protect. 27, 5-8.

Ren, L., Li, L., and Bai, R. (2008). PCR detection of Sporisorium reilianum. J. Maize Sci. 16, 138-139.

Shen, N. X., Yan, N., and Wang, F. (2006). The research of Sporisorium reiliana's infection efficiency and spreading in maize based on PCR assays. Sci. Agric. Sin. 39:6.

Shetty, H. S., and Safeeulla, K. (1979). Stimulation of teliospore germination in smut fungi. Proc. Indian Acad. Sci. B Part 2 Plant Sci. 88, 479-486. doi: 10.1007/BF03046138

Wang, Z. H., Wang, Y. J., Wang, L., Yi, J., Li, X., and Shi, H. (2002). Research advance on head Smut disease in maize. J. Maize Sci. 4, 61-64.

Wei, J. C.(1979). Manual of Fungal Identification. Shanghai: Science and Technology Press.

Wu, X., Pang, Z., and Hu, J. (1981). Study on the environmental factors affecting infection and cultural meadures of controlling corn head smut [Sphacellotheca reiliana (KUHN) CLINT.]. J. Plant Protect. 8, 41-46.

Xiaowei Zhou, L. X., Wang, N., Jiang, Z., Li, L., and Zhang, Y. (2017). Screening of efficient inoculation methods of head smut and common 
smut of corn. J. Northeast Agric. Sci. 42, 28-30. doi: 10.16423/j.cnki.10038701

Xu, M., Melchinger, A., and Lübberstedt, T. (1999). Species-specific detection of the maize pathogens Sporisorium reiliana and Ustilago maydis by dot blot hybridization and PCR-based assays. Plant Dis. 83, 390-395. doi: 10.1094/PDIS. 1999.83.4.390

Yang, D., Wang, N., Yan, X., Shi, J., Zhang, M., Wang, Z., et al. (2014). Microencapsulation of seed-coating tebuconazole and its effects on physiology and biochemistry of maize seedlings. Colloids Surf. B 114, 241-246. doi: 10. 1016/j.colsurfb.2013.10.014

Zhang, F., Ping, J., Du, Z., Cheng, Q., and Huang, Y. (2011). Identification of a new race of Sporisorium reilianum and characterization of the reaction of sorghum lines to four races of the head smut pathogen. J. Phytopathol. 159, 342-346. doi: $10.1111 /$ j.1439-0434.2010.01770.x

Zhang, Z. (1980). Studies on the infection of head smut fungus from corn. J. Northwest Sci. Tech. Univ. Agric. For. (Nat. Sci. Edn.) 4, 67-78.
Conflict of Interest: The authors declare that the research was conducted in the absence of any commercial or financial relationships that could be construed as a potential conflict of interest.

Publisher's Note: All claims expressed in this article are solely those of the authors and do not necessarily represent those of their affiliated organizations, or those of the publisher, the editors and the reviewers. Any product that may be evaluated in this article, or claim that may be made by its manufacturer, is not guaranteed or endorsed by the publisher.

Copyright (c) 2021 Zhang, Fan, Feng, Qiu and Hu. This is an open-access article distributed under the terms of the Creative Commons Attribution License (CC BY). The use, distribution or reproduction in other forums is permitted, provided the original author(s) and the copyright owner(s) are credited and that the original publication in this journal is cited, in accordance with accepted academic practice. No use, distribution or reproduction is permitted which does not comply with these terms. 